\title{
PENERAPAN METODE FINITE STATE MACHINE (FSM) PADA GAME AGENT LEGENDA ANAK BORNEO
}

\author{
Ekawati Yulsilviana $^{1)}$ dan Hanifah Ekawati ${ }^{2)}$ \\ ${ }^{1,2}$ Manajemen Informatika, STMIK Widya Cipta Dharma Samarinda \\ ${ }^{1,2}$ Jl. M. Yamin No.25 Samarinda - Kalimantan Timur 75123 \\ E-mail : ekawicida@gmail.com ${ }^{1)}$,hanifah@wicida.ac.id ${ }^{2)}$
}

\begin{abstract}
ABSTRAK
Finite State Machine merupakan salah satu metodologi perancangan sistem kontrol yang menggambarkan tingkah laku atau prinsip sistem dengan menggunakan tiga hal yaitu state (keadaan), event (kejadian) dan action (aksi). Pada penelitian ini dibuat game yang berjudul "Legenda Anak Borneo" menceritakan petualangan pahlawan Legenda Kalimantan. Sebuah permainan bergenre Tactical Role Playing Game (Tactical RPG). Menggunakan metode FSM (Finite State Machine) dikembangkan pula agen cerdas di dalamnya, dengan tujuan untuk membuat musuh yang dapat menjadi lawan dari pemain. Didalam RPG, agen permainan yang berperan dapat musuh yang dapat berpikir sendiri ini biasa disebut dengan non-player character (NPC).Metode pengembangan sistem yang digunakan yaitu Metode Pengembangan Multimedia. Dengan menerapkan tahapan metode tersebut, maka dihasilkan NPC yang dapat memberi respon atau memiliki tingkah laku sesuai dengan keadaan yang terjadi pada pemain atau NPC lainnya. Hadirnya NPC dengan logika FSM membuat permainan "Legenda Anak Borneo" menjadi menantang.
\end{abstract}

Kata Kunci: Finite State Machine, NPC, Game Agent, Tactical, Role Playing Game

\section{PENDAHULUAN}

Seiring dengan kemajuan teknologi, game modern atau game yang disajikan pada suatu piranti atau perangkat teknologi dan dimainkan secara virtual juga semakin berkembang (Afriany dkk,2018). Perangkat mobile atau smartphone yang makin maju sekarang dapat menjalankan game dari yang sederhana sampai game yang memiliki fiur dan Tampilan yang tidak kalah dengan game yang ada di komputer (Wijayanti dkk, 2018). Game pada umumnya menggunakan artificial intelligecne pada sistemnya agar membuat game tersebut lebih menarik untuk dimainkan (Andrea dkk, 2014). Artificial intelligence diterapkan pada agen game tersebut yang berupa Non Player Character NPC dan musuh atau lawan yang harus dihadapi didalam game (Karamian, 2016)

Salah satu penerapan kecerdasan buatan di game untuk pengambilan keputusan yang cerdas adalah Finite State Machine (FSM) (Jones, 2015). Metode finite state machine sendiri dipilih karena merupakan metode yang cukup sederhana namun sangat baik dalam memodelkan prilaku agen. Metode finite state machine menggunakan state (kondisi), event (kejadian) dan action (aksi). yang saling berkaitan. Penerapan metode finite state machine pada agen digunakan agar agen dapat terlihat seperti mengambil keputusan saat state yang terdapat pada agen tersebut terpenuhi (Andrea \& Palupi, 2018). Didalam RPG, agen permainan yang berperan dapat sebagai musuh ini biasa disebut dengan NPC.

Berdasarkan uraian diatas maka tim peneliti tertarik untuk mengembangkan mobile game khusus pada smartphone berbasis android yang berjudul "Legenda
Anak Borneo". Sebuah permainan yang menceritakan petualangan pahlawan Legenda Kalimantan. Game tersebut akan memakai metode finite state machine dan akan menggunakan genre Tactical RPG. Genre Tactical $R P G$ sendiri diambil karena sangat cocok untuk menguji kefektifan FSM di dalam logika berpikir NPC.

\section{RUANG LINGKUP}

Permasalahan difokuskan pada:

1. Penerapan metode FSM pada game Agen "Legenda Anak Borneo".

2. Penerapan FSM hanya pada NPC enemy dari game "Legenda Anak Borneo".

3. Dengan diterapkannya NPC dapat mengambil keputusan terhadap kondisi yang terjadi di dalam game.

\section{BAHAN DAN METODE}

Adapun bahan dan metode yang gunakan dalam membangun game ini yaitu:

\subsection{Tactical RPG}

Menurut Jasson, 2009, Role Playing Game merupakan permainan dimana pemain dapat melakukan kendali terhadap satu atau lebih karakter yang dirancang sendiri oleh pemain dan membantu pemain untuk menyelesaikan misi (quest) yang diberikan oleh komputer. Keberhasilan dalam menyelesaikan game bergenre role playing game bergantung pada diselesaikannya semua quest yang ada. Tactical RPG atau sering dikenal dengan strategy RPG, percampuran antara elemen game strategy pada dengan proses 
perkembangan karakter seperti RPG. Seperti RPG sederhana, game ini mengontrol beberapa karakter, baik personal atau grup/party, untuk melawan musuh namun perlu diperhatikan secara isometric pergerakan karakter/grup dalam bertempur baik dari segi arah (isometric grid) dan dari segi pergerakan strategical game (manual game). Perkembangan karakter seperti kekuatan dan kemampuan (abilities) merupakan kunci utama dalam permainan RPG. Quest yang diberikan dapat berupa taktik pertarungan, logistic, pertumbuhan ekonomi, eksplorasi dan penyelesaian teka-teki.

\subsection{Finite State Machine}

Millington dan Funge, 2009, Finate State Machines (FSM) adalah sebuah metodologi perancangan sistem kontrol yang menggambarkan tingkah laku atau prinsip kerja sistem dengan menggunakan state (Keadaan), event (kejadian) dan action (aksi).

Dalam state machine sistem menempati satu state (keadaan). Sistem akan beralih atau bertransisi menuju ke state lain jika mendapatkan masukan event tertentu. Sistem akan tetap melakukan aksi yang sama pada suatu state sampai sistem menerima event tertentu baik yang berasal dari perangkat luar atau komponen dari sistem itu sendiri. Setiap state terhubung oleh transisi dan setiap transisinya mengarah ke satu state lainnya. Transisi keaadan ini umumnya juga disertai oleh aksi yang dilakukan oleh sistem ketika menanggapi masukan yang terjadi. Aksi yang dilakukan tersebut dapat berupa aksi sederhana yang melibatkan rangkaian proses yang relatif rumit

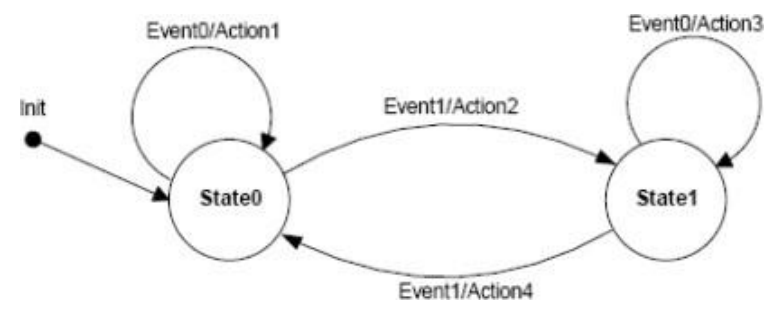

Gambar 1. Diagram state sederhana

Diagram pada gambar 1, memperlihatkan FSM dengan dua buah state dan dua buah input serta empat buah aksi output yang berbeda : seperti terlihat pada gambar, ketika sistem mulai dihidupkan, sistem akan bertransisi menuju state0, pada keadaan ini sistem akan menghasilkan Action 1 jika terjadi masukan Event0, sedangkan jika terjadi Event1 maka Action2 akan dieksekusi kemudian sistem selanjutnya bertransisi ke keadaan State 1 dan seterusnya.

Ada beberapa teknik pemodelan abstrak yang bisa digunakan untuk membantu defenisi atau pemahaman dan desain dari FSM.

1. Diagram Transisi State

2. Diagram Pengambilan Keputusan State-Aksi.

3. Diagram Grafik State

4. Analisa Hirarki Perintah
Menurut Asmiatun \& Putri, 2017, Pada dasarnya implementasi FSM bisa dibagi menjadi tiga (3) cara, dimana masing-masing cara memiliki kelebihan dan kekurangan masing-masing.

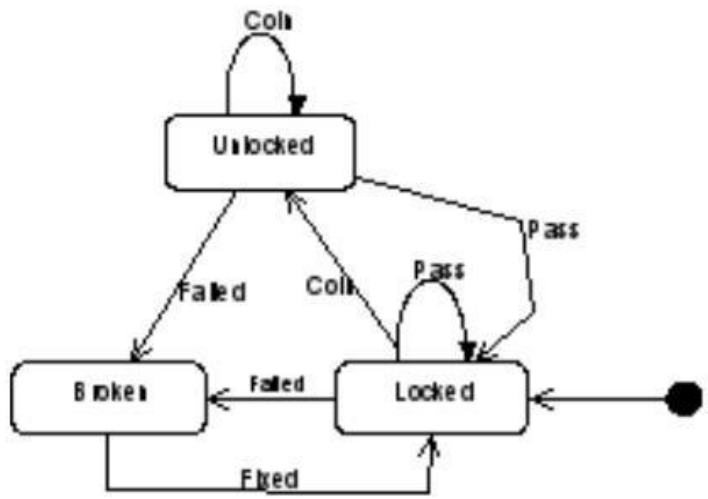

\section{Gambar 2. FSM mesin minuman dalam kaleng menggunakan koin}

Sebagai contoh sistem yang digunakan untuk melihat perbedaan antara cara satu dengan yang lain adalah sistem mesin minuman dalam kaleng menggunakan koin. Desain FSM sistem tersebut tampak pada gambar 2 .

\section{Cara tradisional}

Menurut Asmiatun \& Putri, 2017, Kelebihan dari cara tradisional adalah mudah untuk diimplementasikan. Cara ini adalah cara klasik yang paling mudah untuk menerapkan FSM pada perangkat lunak sekaligus merupakan cara klasik yang biasanya masih banyak digunakan pada mikro komputer dengan sumber daya pemroses yang terbatas (limited hardware resources). Contoh cara tradisional dapat dilihat pada script dibawah ini.

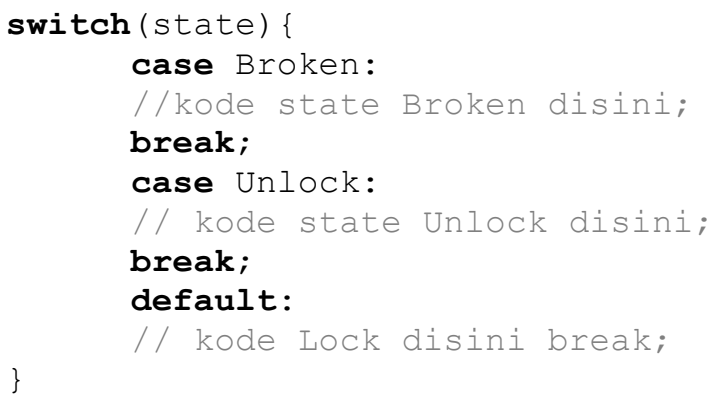

\section{Lookup table}

Menurut Wibowo, 2018, Cara lain mengimplementasikan FSM dalam perangkat lunak adalah dengan menggunakan lookup table. Tabel ini berisi semua transisi state yang mungkin terjadi pada sistem. Tabel ini direpresentasikan sebagai matriks pada kode program dimana tiap baris merepresentasikan event atau transisi state dan kolomnya merepresentasikan state sedangkan elemennya merepresentasikan next state. 
Salah satu contoh lookup tabel yang digunakan adalah seperti pada tabel 1

Tabel 1. Contoh Lookup table FSM

\begin{tabular}{|l|l|l|l|}
\hline & Unlock & Lock & Broken \\
\hline Coin & & Unlock & \\
\hline Pass & Lock & & \\
\hline Failed & Broken & Broken & \\
\hline Fixed & & & Lock \\
\hline
\end{tabular}

\section{Object Oriented}

Menurut Wibowo, 2018, Kelebihan penggunaan OOP pada FSM adalah fleksibilitasnya yang tinggi dan pemeliharaannya yang mudah baik pada sistem yang sederhana, menengah, maupun sistem yang kompleks (Yacoub, 1998: 1998). Selain itu juga mendapatkan manfaat dari salah satu kelebihan OOP yaitu penggunaan kembali kode yang telah diketik (code reusability) sehinga pengetikan kode menjadi lebih sedikit.

\subsection{Metode Pengembangan Multimedia}

Metodologi pengembangan multimedia terdiri dari enam tahap, yaitu concept (pengonsepan), design (pendesainan), meterial collecting (pengumpulan materi), assembly (pembuatan), testing (pengujian), dan distribution (pendistribusian). Keenam tahap ini tidak dapat bertukar posisi. Meskipun begitu, tahap concept memang harus menjadi hal yang pertama kali dikerjakan (Agarwal, 2010)

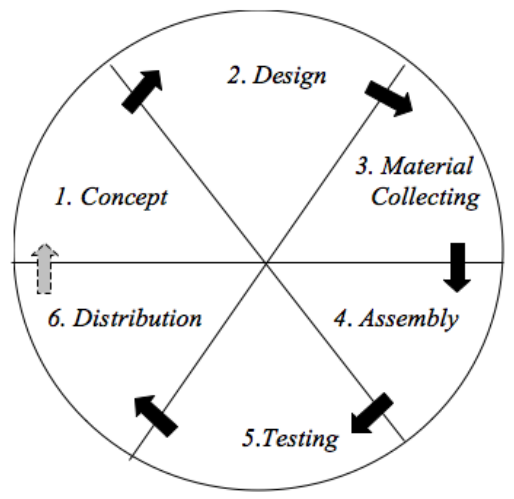

Gambar 3. Tahapan Pengembangan Multimedia

Tahapan Pengembangan Multimedia pada gambar 3 meliputi :

1. Concept

Tahap concept (pengonsepan) adalah tahap untuk menetukan tujuan dan siapa pengguna program (identifikasi audiens). Tujuan dan pengguna akhir program berpengaruh pada nuansa multimedia sebagai pencerminan dari identitas organisasi yang menginginkan informasi sampa pada pengguna akhir. Karakteristik pengguna termasuk kemampuan pengguna juga perlu dipertimbangkan karena dapat memengaruhi pembuatan desain.
Selain itu, tahap ini juga akan menentukan jenis aplikasi (presentasi,interaktif,dan lain-lain). Dasar aturan untuk perancangan juga ditentukan pada tahap ini, misalnya ukuran aplikasi, target, dan lain-lain. Output dari tahap ini biasanya berupa dokumen yang bersifat naratif untuk mengungkapkan tujuan projek yang ingin dicapai.

\section{Design}

Design (perancangan) adalah tahap pembuatan spesifikasi mengenai arsitektur program, gaya, tampilan, dan kebutuhan material/bahan untuk program. Spesifikasi dibuat serinci mungkin sehingga pada tahap berikutnya, yaitu material collecting dan assembly, pengambilan keputusan baru tidak diperlukan lagi, cukup menggunakan keputusan yang sudah ditentukan pada tahap ini. Meskipun demikian, pada praktiknya, pengerjaan proyek pada tahap awal masih akan sering mengalami penambahan bahan atau pengurangan bagian aplikasi, atau perubahanperubahan lain.

Tahap ini biasanya menggunakan storyboard untuk menggambarkan deskripsi tiap scene, dengan mencantumkan semua objek multimedia dan tautan ke scene lain dan bagian alir (flowchart) untuk menggambarkan aliran dari satu scene ke scene lain. Pembuatan storyboard dapat menggunakan cara pembuatan storyboard film/animasi.

\section{Material Collecting}

Material Collecting adalah tahap pengumpulan bahan yang sesuai dengan kebutuhan yang dikerjakan.Bahan-bahan tersebut, antara lain gambar clip art, foto, animasi, video, audio, dan lain-lain yang dapat diperoleh secara gratis atau dengan pemesanan kepada pihak lain sesuai dengan rancangannya. Tahap ini dapat dikerjakan secara paralel dengan tahap assembly. Namun, pada beberapa kasus, tahap material collecting dan tahap assembly akan dikerjakan secara linear dan tidak paralel.

4. Assembly

Tahap assembly adalah tahap pembuatan semua obyek atau bahan multimedia. Pembuatan aplikasi didasarkan pada tahap design, seperti storyboard, bagan alir, dan/atau struktur navigasi.

\section{Testing}

Tahap Testing (pengujian) dilakukan setelah menyelesaikan tahap pembuatan (assembly) dengan menjalankan aplikasi/program dan melihatnya apakah ada kesalahan atau tidak.

\section{Distribution}

Pada tahap ini, aplikasi akan disimpan dalam suatu media penyimpanan. Jika media penyimpanan tidak cukup untuk menampung aplikasinya, kompresi terhadap aplikasi tersebut akan dilakukan. Tahap ini juga dapat disebut tahap evaluasi untuk pengembangan produk yang sudah jadi supaya menjadi lebih baik. Hasil evaluasi ini dapat digunakan sebagai masukan untuk tahap concept pada produk selanjutnya. 


\section{KONSEP APLIKASI}

Konsep game "Legenda Anak Borneo" ini menggunakan Unified Modeling Language (UML). Game berbasis android ini menggunakan alat bantu UML sebagai salah satu cara untuk mempermudah dalam pembuatan aplikasi ini.

1. Diagram Use Case Game "Legenda Anak Borneo"

Use case mendeskripsikan sebuah interaksi antara satu atau lebih aktor dengan sistem yang akan dibuat (Nugroho, 2101). Secara kasar, use case digunakan untuk mengetahui fungsi apa saja yang ada di dalam sebuah sistem dan siapa saja yang berhak menggunakan fungsi-fungsi tersebut. Ada dua hal utama pada use case yaitu pendefinisian apa yang disebut aktor dan use case. Pada diagram use case "Legenda Anak Borneo" terdapat 10 use case yang dapat dilihat pada gambar 4.

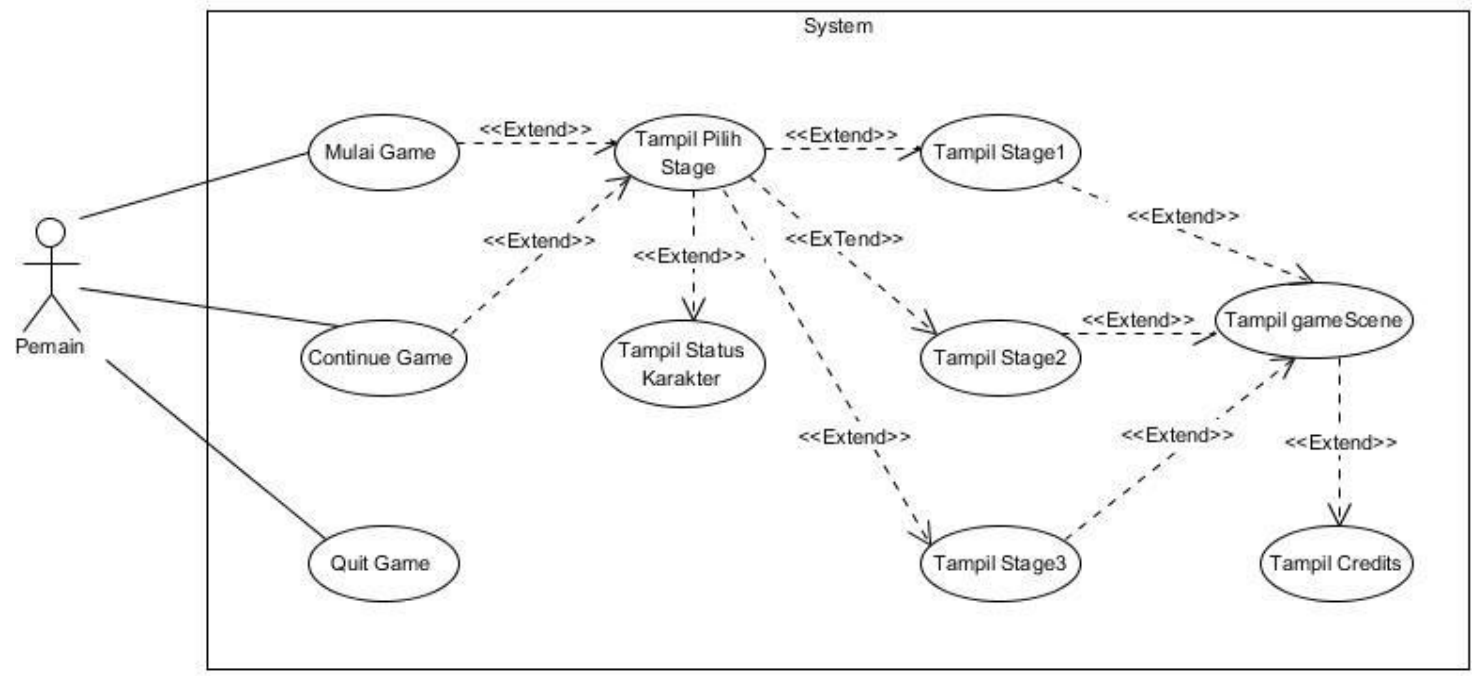

Gambar 4. Diagram Use Case game "Legenda Anak Borneo"

2. Activity Diagram "Legenda Anak Borneo"

Diagram pada gambar 5, menggambarkan tentang aktifitas yang terjadi pada sistem. Dari pertama sampai akhir, diagram ini menunjukkan langkah - langkah dalam proses kerja sistem dan jalur-jalur aktifitas dari level atas secara umum pada game "Legenda Anak Borneo". Sebuah aktifitas dapat direalisasikan oleh satu use case atau lebih.

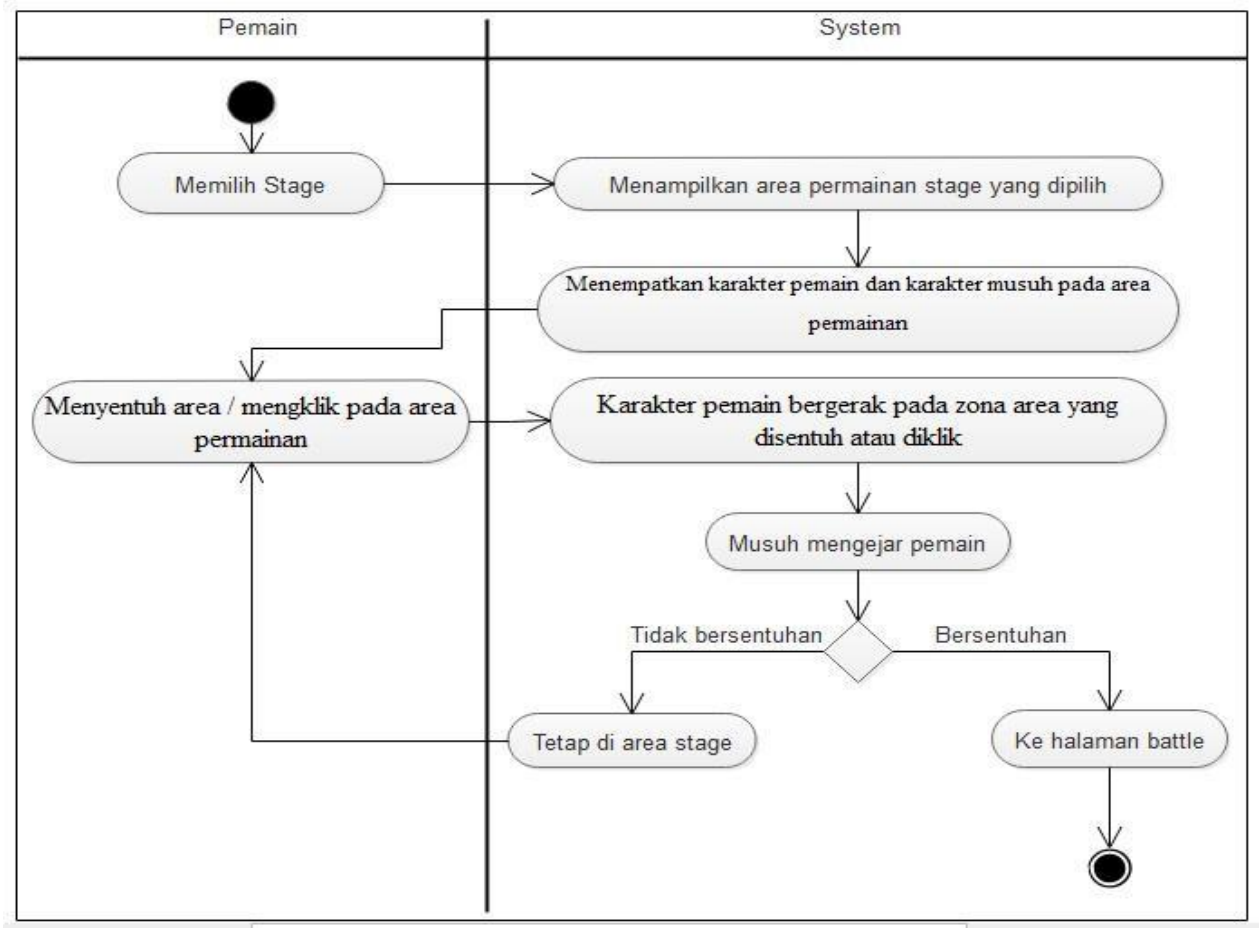

Gambar 5. Activity Diagram Tampil Stage 
3. Class Diagram Game "Legenda Anak Borneo"

Perancangan Artificial Intelligence pada penelitian ini diterapkan pada pengaturan perilaku NPC dengan metode finite state machine". Pada artikel ini dibahas salah satu NPC yang dibangun dengan inisial agen 01. Class diagram agen 01 seperti pada gambar 6 .

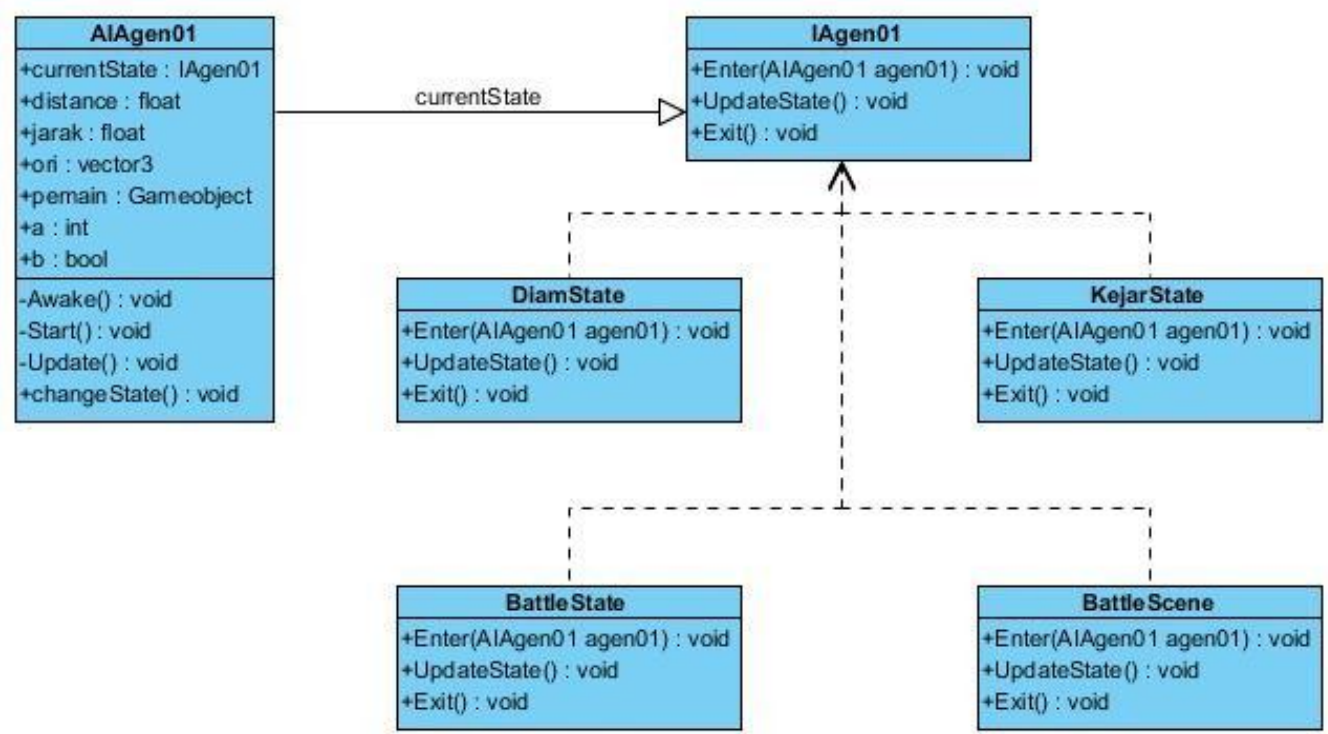

Gambar 6. Class Diagram Agen 01

4. Finite State Machine Agen "Legenda Anak Borneo" Agen 01 hanya terdapat pada area stage.

Agen 01 tidak memiliki atribut health, attack, defense seperti Agen 02. Tujuan Agen 01 adalah mengejar pemain yang berada dalam jarak tertentu dari Agen 01. Pada FSM Agen 01 State digambarkan berbentuk kotak dan event yang digambarkan berbentuk panah. Proses perpindahan state-state pada Agen 01 dapat dilihat pada gambar 6.

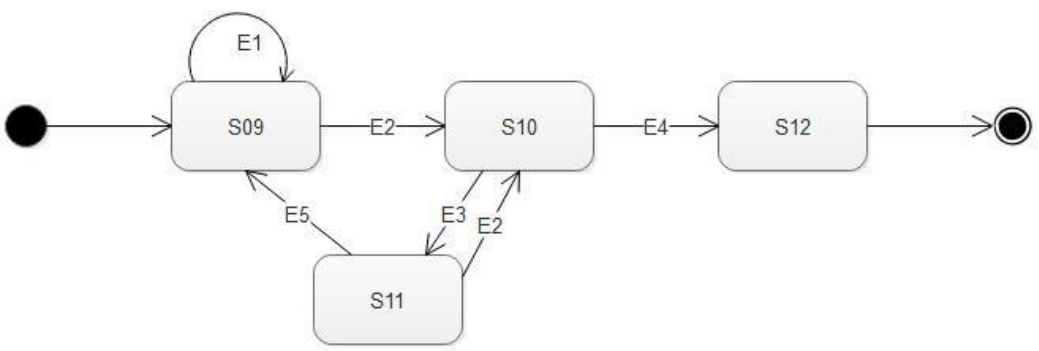

Gambar 6. Diagram Finite State Machine Agen 01

Keterangan gambar 6:

S09- NPC diam

S10 - NPC mengejar

S11 - NPC kembali ke zona awal

S12 - NPC menangkap pemain

5. Diagram Transisi NPC Game "Legenda Anak Borneo"

Pada tabel 2 dijelaskan transisi tiap state agen 01 . State awal berada pada kolom sebelah kiri dengan menggunakan warna abu-abu dimulai dari S9 dan berurutan ke bawah sampai S12. Event berada pada kolom bagian atas yang berwarna abu-abu, dimulai dari E1 dan berakhir di E5. State akhir berada pada kolom tengah yang berwarna putih dan tidak beraturan karena state akhir ditentukan oleh state awal dan event.
E1/E5 - tidak ada pemain mendekat E2 - pemain memasuki zona agen E3 - pemain menjauhi zona agen E4 - pemain diam

Tabel 2. Tabel Transisi Agen 01

\begin{tabular}{|l|c|c|c|c|c|}
\hline \multirow{2}{*}{$S$} & \multicolumn{5}{|c|}{ INPUT } \\
\cline { 2 - 6 } & E1 & E2 & E3 & E4 & E5 \\
\hline S09 & S09 & S10 & & & \\
\hline S10 & & & S11 & S12 & \\
\hline S11 & & S10 & & & S09 \\
\hline S12 & & & & & \\
\hline
\end{tabular}




\section{PEMBAHASAN}

Hasil desain dan assembly berdasarkan konep adalah sebagai berikut :

1. Desain Objek Karakter 3D

Objek-objek yang terdapat di dalam game berbentuk 3 dimensi. Dibuat menggunakan software Blender. Karakter utama adalah karakter yang dikendalikan oleh pemain (Kopel \& Hajas, 2018). Karakter ini berbentuk kesatria legenda kalimantan. Terdapat 5 karakter dengan perbedaan terletak pada senjata yang digunakan pemain. Contoh karakter utama dapat dilihat pada gambar 7 .

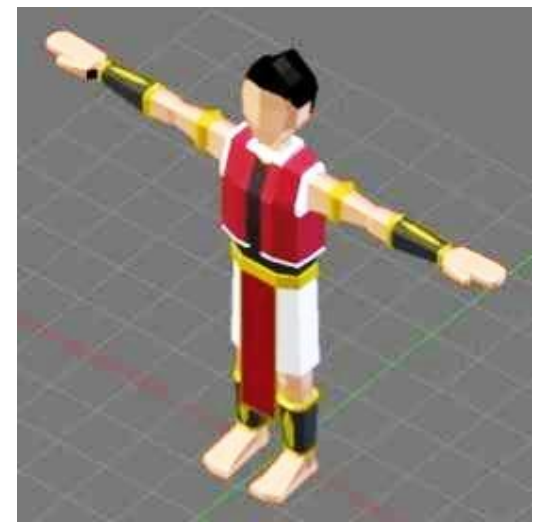

Gambar 7. Karakter Utama

\section{Assembly Tampilan Antarmuka Game}

Pada tahap ini pembuatan antarmuka yang terdapat pada game "Legenda Anak Borneo". Di tampilan awal game (Gambar 8) terdapat 3 buah tombol, yaitu tombol start game, tombol continue game dan tombol quit game. Tombol start game akan memulai baru permainan dan menampilkan halaman pemilihan stage. Tombol continue game akan menampilkan halaman pemilihan stage berdasarkan data yang telah disimpan oleh pemain. Tombol quit game akan menutup permainan.

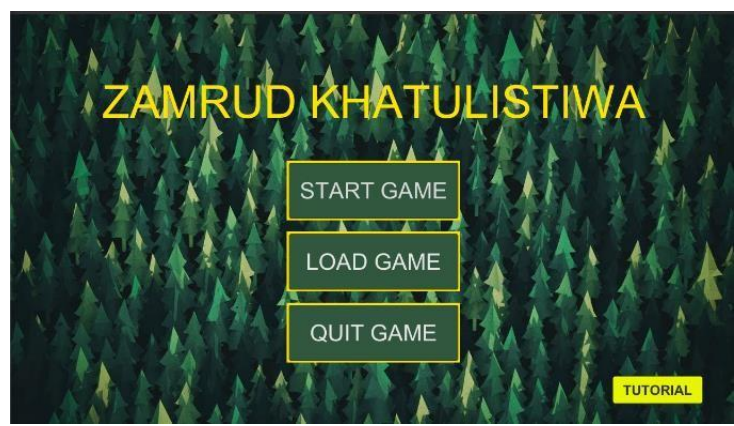

Gambar 8. Tampilan Awal Game

Tampilan Area Stage 1 (Gambar 9) dimana pemain dapat menyentuh pada area tertentu dan karakter pemain akan bergerak kearah tersebut. Terdapat 1 tombol dikanan atas yang dapat membawa pemain ke tampilan status karakter.

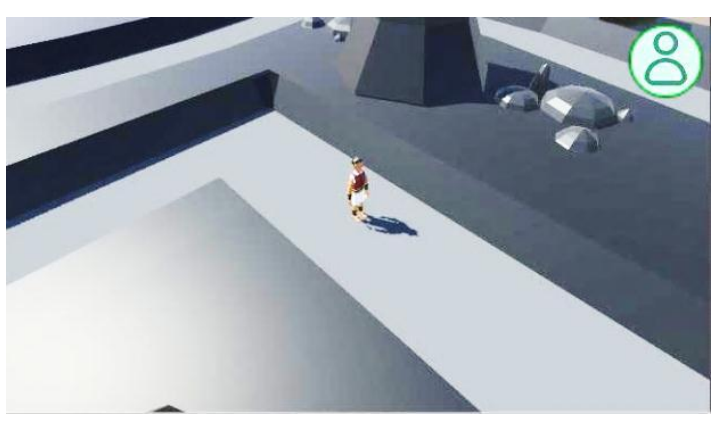

Gambar 9. Tampilan Area Stage 1

Ditampilan scene battle (Gambar 10) terdapat tombol move, attack, end turn, skill 1 dan skill 2. Dikiri terdapat status Health Point (HP) dan gambar karakter agen enemy. Disebelah kanan terdapat gambar dan status HP karakter pemain.

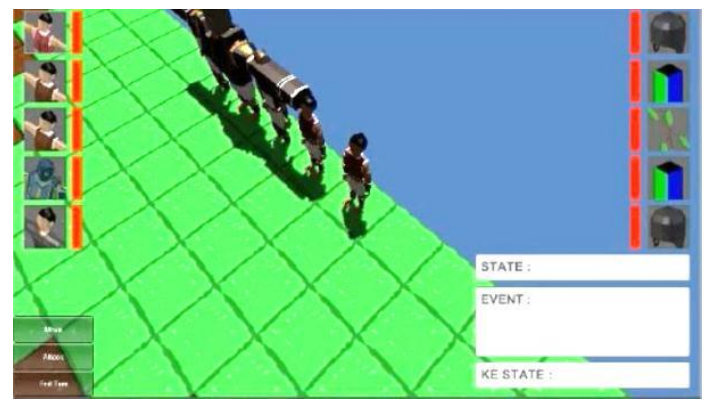

Gambar 10. Tampilan Scene Battle

3. Assembly Finite State Machine Agen

Finite state machine disini untuk melihat perubahan perilaku NPC enemy terhadap permainan yang sedang berjalan. Pembuatan state - state 3 agen dengan setiap perubahan state yang terjadi pada masing-masing agen. Agen 01 memiliki 4 state dan 5 event, yaitu :

\section{1) State Diam}

Pada awal halaman stage dimulai, agen 01 akan diam pada posisinya atau koordinat awal seperti pada gambar 11. Dapat diliihat tanda lingkaran pada gambar 11 perwujudan NPC agan 01 dalam bentuk monster batu.

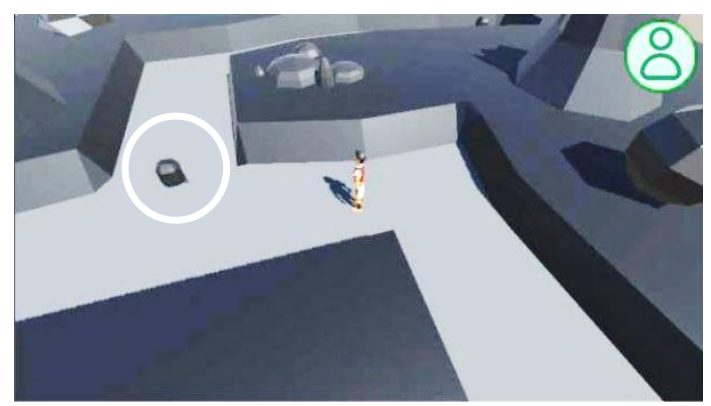

Gambar 11. Agen 01 State Diam 
2) State Kejar

Ketika pemain berada dalam jarak zona agen, maka aksi agen 01 akan berganti ke state kejar seperti pada gambar 12.

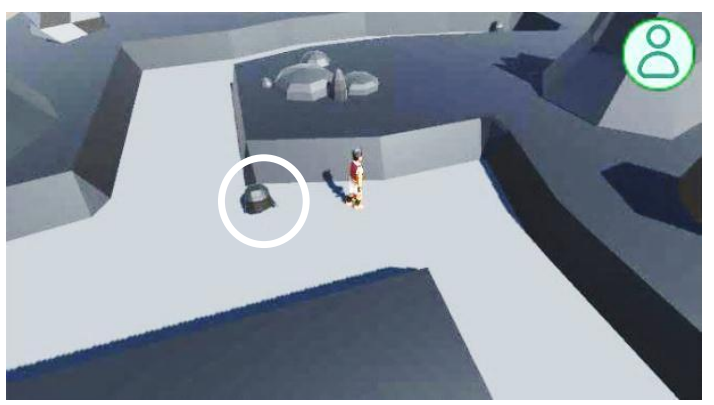

Gambar 12. Agen 01 State Kejar

3) State Kembali

Ketika pemain berada diluar zona yang telah ditentukan maka agen 01 akan berganti ke state kembali, yaitu bergerak menuju posisi awal agen 01 seperti pada gambar 13 .

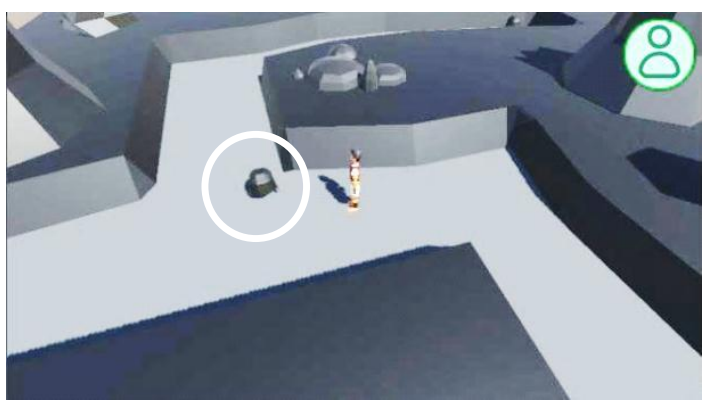

Gambar 13. Agen 01 State Kembali

4) State Menangkap

Ketika pemain dan agen 01 bersentuhan seperti gambar 14, maka aksi akan berganti ke menangkap pemain. Permaina akan menuju ke scene battle seperti pada gambar 10 di halaman sebelumnya.

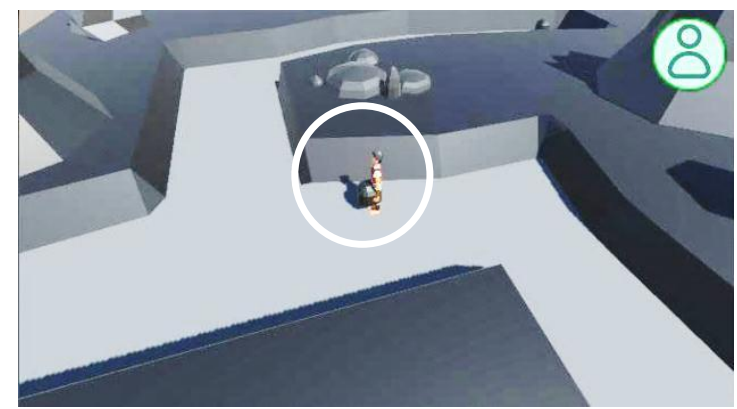

Gambar 14. Agen 01 State Battle

\section{KESIMPULAN}

Pengembangan game "Legenda Anak Borneo" melalui 6 tahap yaitu konsep, desain, penguumpulan bahan, assembly, pengujian dan pendistribusian. Penerapan metode Finite State Machine dengan membuat state, action dan event pada tiap NPC yang dibuat. Fungsi Finite State Machine pada NPC untuk menentukan respon perilaku NPC terhadap perubahan kondisi yang terjadi pada pemain dan pada lingkungan game. Di dalam game ini pemain dapat melawan agen enemy dan menjelajah tiap stage-stage yang tersedia.

\section{SARAN}

Di masa yang akan datang metode finite state machine ini, dapat diterapkan pada berbagai tipe genre game, yang nantinya akan memberikan keunikan tersendiri didalamnya. Game menjadi lebih seru dan lebih menantang dengan bantuan metode finite state machine. Dengan memperbanyak state-state dan eventevent diharapkan dapat membuat pergerakan atau perilaku agen lebih bervariasi dan lebih baik lagi. Memperbanyak tipe agen kedalam game juga akan memperbanyak variasi agen yang bisa digunakan dengan kelebihan dan kekurangan masing-masing agen.

\section{DAFTAR PUSTAKA}

Afriany, J., Andrea, R., Yulsilviana, E., Wijayanti, S., \& Nabile, D. 2018. Program Pengabdian Masyarakat: Alat Bantu Belajar Ilmu Batuan Berbasis Android pada Kelas Geologi Tambang Smk Negeri 1 Sendawar. Sebatik, 22(2), 202-210.

Agarwal, B. B., Tayal, S. P., dan Gupta, M., 2010. Software Engineering and Testing, Burlington, USA: Jones \& Bartlett Learning.

Andrea, R., \& Palupi, S. 2018. Membangun Edugame "Boni Kids-Borneo Animal Kids" Permainan Match-up dengan Teknik Pengacakan Shuffle dan Pengembangan Agen Cerdas dengan Model Finite State Machine (Fsm). Sebatik, 19(1), 6-10.

Andrea, R., Akbar, R. I., \& Fitroni, M. 2014. Developing battle of Etam earth game agent with finite state machine (FSM) and sugeno fuzzy. ICCS Proceeding, 1(1), 184-187.

Asmiatun, S., \& Putri, A. N. (2017). Belajar Membuat Game 2D dan 3D Menggunakan Unity. Deepublish.

Jasson. 2009. Role Playing Game (RPG) Maker.Yogyakarta : Andi.

Jones, M. T. 2015. Artificial Intelligence: A Systems Approach: A Systems Approach. Jones \& Bartlett Learning.

Karamian, V. 2016. Building an RPG with Unity 5. x. Packt Publishing Ltd.

Kopel, M., \& Hajas, T. 2018. Implementing AI for Nonplayer Characters in 3D Video Games. In Asian Conference on Intelligent Information and Database Systems (pp. 610-619). Springer, Cham. 
Millington, I., \& Funge, J. 2009. Artificial intelligence for games. CRC Press.

Nugroho, A. 2010. Rekayasa perangkat lunak berorientasi objek dengan metode USDP. Penerbit Andi.

Wibowo, F. W. 2018. FPGA DAN VHDL: Teori, Antarmuka dan Aplikasi. Deepublish.

Wijayanti, S., Nurhuda, A., \& Andrea, R. 2018. Edugame "Etam-Tainment" Pembelajaran Bahasa Kutai dengan Shuffle Random dan Agen Cerdas.
Jurnal Nasional Teknik Elektro dan Teknologi Informasi (JNTETI), 7(3).

\section{UCAPAN TERIMA KASIH}

Publikasi ini dibiayai oleh:

Direktorat Riset dan Pengabdian Masyarakat Direktorat Jenderal Penguatan Riset dan Pengembangan Kementerian Riset, Teknologi, dan Pendidikan Tinggi sesuai dengan Kontrak Penelitian Tahun Anggaran 2019 